\title{
APLIKASI TATA LETAK MUATAN PADA KAPAL BARANG MENGGUNAKAN PERHITUNGAN TONASE
}

\author{
Tono $^{1}$, Dwi Nurul Huda ${ }^{2}$, Ricak Agus Setiawan ${ }^{3}$ \\ 1,2,3 Sekolah Tinggi Teknologi Indonesia Tanjungpinang \\ Jln. Brigjen Katamso No. 92 Tanjungpinang Kepulauan Riau Indonesia

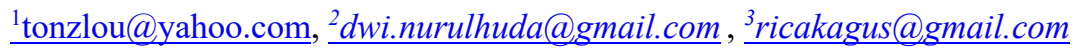

\begin{abstract}
Intisari-Aplikasi Tata Letak Muatan Pada Kapal Barang merupakan suatu sistem yang dirancang untuk membantu perwira kapal dalam mendapatkan informasi mengenai barang yang dimuat diatas kapal. Proses muat barang yang tidak tertata menyebabkan kesulitan saat proses bongkar dan menjadi suatu kemungkinan besar barang akan rusak akibat barang lain yang dimuat. Kapten dan Mualim II selaku perwira yang mengambil keputusan alur laut yang akan dilalui kapal wajib mengetahui berat keseluruhan dari kapal. Mualim I sebagai pengontrol barang yang akan dimuat keatas kapal hanya dapat memberi instruksi dalam bentuk komunikasi biasa. Selain itu terkadang buruh bongkar muat kebingungan saat di beri instruksi untuk mengambil suatu barang muatan disuatu tujuan karena mereka tidak melihat langsung proses penempatan muatan barang. Dengan demikian diharapkan aplikasi ini dapat menjadi solusi permasalahan yang timbul tersebut.

Kata Kunci :Muatan, Kapal, Tonase
\end{abstract}

Abstract-The Cargo Application on Cargo Ships is a system designed to assist ship officers in obtaining information about goods loaded on board. The unorganized loading process causes difficulties during the unloading process and it is highly likely that the goods will be damaged due to other goods being loaded. The captain and mualim II as officers who make decisions about the sea lanes the ship will pass must know the overall weight of the ship. The First Officer as controller of the goods to be loaded onto the ship can only give instructions in the form of ordinary communication. In addition, sometimes the loading and unloading workers are confused when given instructions to take a cargo at a destination because they do not see directly the process of placing the cargo. Thus, it is hoped that this application can be a solution to the problems that arise.

Keywords: cargo ,ship,tonase

\section{Pendahuluan}

\section{A. Latar Belakang}

Kemajuan perekonomian global mendorong pertumbuhan pesat disalah satu sektor yaitu jasa. Menurut Fandy Tjiptono dalam buku "Manajemen Jasa"(2006: 6) mengatakan bahwa “jasa merupakan aktivitas manfaat atau kepuasan yang ditawarkan untuk dijual dan merupakan komponen yang tumbuh paling cepat, baik dalam perdagangan maupun investasi langsung luar negeri (foreign direct investment)" dengan kesimpulan bahwa jasa merupakan suatu tindakan atau kegiatan yang ditawarkan oleh satu pihak kepada pihak lain yang pada hakekatnya jasa tersebut tidak berwujud.

Dengan perkembangan teknologi informasi yang ada pada saat ini maka memudahkan dalam melakukan pengolahan data , hingga menghasilkan suatu informasi yang dibutuhkan dengan akurat dan mengefektifkan waktu, serta biaya yang lebih efisien

Perusahaan pelayaran merupakan perusahaan yang bergerak dibidang jasa angkut barang dari pulau ke pulau lain atau dari negara ke negara lain. Permasalahan yang terjadi ialah pada proses muat tanpa memikirkan jenis barang dan maksimal kapasitas tampungan, sehingga dapat menimbulkan masalah terhadap kondisi barang tersebut ketika kapal sampai dipelabuhan tujuan nantinya. Padahal setiap kapal sebenarnya memiliki beban maksima dalam memuat suatu barang

B. Identifikasi Masalah

Berdasarkan uraian latar belakang masalah yang telah diuraikan di atas, maka dapat diidentifikasikan beberapa masalahnya sebagai berikut :
1. Kesulitan mendapatkan data jumlah berat muatan yang ada dikapal sehingga menjadi suatu masalah bagi perwira dek kendali kapal.

2. Kapal belum memiliki suatu sistem yang dapat membantu pendataan barang muatan.

3. Proses muat barang kedalam kapal yang tidak tertata sesuai jenis menimbulkan resiko rusaknya barang muatan diatas kapal.

\section{Tujuan Penelitian}

Tujuan dari penelitian ini adalah :

- Membantu penataan barang muatan kapal.

- Membantu memudahkan proses bongkar muat barang muatan.

\section{Kajian Pustaka}

1) Definisi Aplikasi

Aplikasi adalah suatu subkelas perangkat lunak komputer yang memanfaatkan kemampuan komputer langsung untuk melakukan suatu tugas yang diinginkan pengguna yang mengintegrasikan berbagai kemampuan komputer, tapi tidak secara langsung menerapkan kemampuan tersebut untuk mengerjakan suatu tugas yang menguntungkan pengguna.

Dalam pengembangannya, aplikasi dibedakan menjadi aplikasi desktop, aplikasi web dan aplikasi mobile. Aplikasi yang hanya dapat dijalankan di perangkat komputer/PC disebut aplikasi desktop. Aplikasi web yang dijalankan jika ada koneksi internet. Sedangkan aplikasi mobile adalah aplikasi yang dapat dijalankan di perangkat mobile. Suatu aplikasi dapat berjalan di berbagai 
perangkat dioperasikan oleh OS (Operating System) yang terdapat dalam perangkat tersebut.[1].

\section{2) Transportasi}

Transportasi diartikan sebagai suatu proses pemindahan barang maupun manusia dari tempat asal ke tempat tujuan. Proses pengangkutan merupakan gerakan dari tempat asal, dari mana kegiatan angkutan dimulai, ke tempat tujuan, dan kemana kegiatan pengangkutan diakhiri.

Transportasi memegang peranan penting dalam dinamika masyarakat bahkan dinamika negara dan bangsa, baik dalam kehidupan sehari-hari, kehidupan budaya, kehidupan politik, terutama dalam kehidupan sosial ekonomi.

Perkembangan suatu masyarakat atau daerah tergantung pada perkembangan transportasi atau sebaliknya, perkembangan transportasi suatu negara dan masyarakat tergantung pada perkembangan aktivitas atau kegiatan perdagangan dan bisnis dari suatu negara atau masyarakat tersebut. Lima unsur pokok transportasi yaitu :

- Manusia, yang membutuhkan transportasi.

- Barang, yang diperlukan manusia

- Kendaraan, sebagai sarana transportasi

- Jalan, sebagai prasarana transportasi

- Organisasi [2]

\section{3) Tata Ruang}

Perancangan tata ruang merupakan suatu kegiatan pemikiran dan penetapan segmen-segmen ruang di dalam suatu gudang maupun ruang muatan kapal serta pengaturan barang-barang muatan di dalam ruang muatan tersebut agar barang muatan terhindar dari kerusakan yang diakibatkan oleh jenis barang muatan lain. Berikut bagian-bagian dalam suatu kapal yaitu :

- Ruang muatan cair (liquid cargo tank) Ruang muatan yang digunakan untuk muatan barangbarang cair maupun cairan mudah terbakar

- Ruang muatan dingin (refrigerated cargo hold)

Ruang muatan yang digunakan untuk muatan barang barang cair maupun cairan mudah terbakar

- Ruang muatan kering (dry cargo hold)

Ruang muatan yang digunakan untuk muatan barangbarang kering

\section{4) Pengangkutan}

Pengangkutan merupakan kegiatan transportasi dalam memindahkan barang dan penumpang dari satu tempat ke tempat lain atau dapat dikatakan sebagai kegiatan ekspedisi.salah satu jenis pengangkutan yakni pengangkutan laut yang merupakan usaha pelayaran niaga yang bergerak dalam bidang penyediaan jasa angkutan muatan laut dimana kegiatan usahanya sangat luas bidangnya serta memegang peranan penting untuk memajukan perdagangan dalam dan luar negeri termasuk didalam usahanya memperlancar arus barang dari daerah produksi ke daerah konsumen. pengangkutan memiliki tujuan yaitu meningkatkan daya guna dan nilai baik barang maupun penumpang yang diangkut dari satu pelabuhan menuju ke pelabuhan tujuan.[3]

\section{5) Muatan}

Muatan merupakan objek dari proses pengangkutan dalam proses pengiriman melalui transportasi darat, laut dan udara. Dengan melayani proses mengangkut muatan dari suatu daerah ke daerah lain perusahaan yang melayani jasa pengiriman dapat memperoleh pendapatan sesuai barang muatan dan lama pengiriman barang muatan tersebut. Meningkatnya kegunaan dan nilai barang maupun penumpang tersebut dimungkinkan dengan adanya kegiatan pemindahan barang dan penumpang dengan alat pengangkutan dari suatu tempat dimana kegunaan dan nilai barang dan penumpang tersebut terlalu rendah, menuju ke tempat lain yang kegunaan dan nilainya relatif lebih tinggi. Begitupun dengan penyelenggaraan pengangkutan laut, dalam hal mana fungsinya juga dimaksudkan untuk meningkatkan kegunaan dan nilai barang maupun penumpang yang diangkut dari satu pelabuhan menuju pelabuhan tujuan pengangkutan. Muatan terbagi dalam beberapa jenis yaitu muatan curah (bulk cargo) dan muatan dalam peti kemas (container).

Container atau peti kemas merupakan kotak yang yang memeunuhi persyaratan teknis dengan berat muatan bersih/payload yang bisa diangkut adalah $21.800 \mathrm{~kg}$ untuk 20 kaki, $26.680 \mathrm{~kg}$ untuk 40 kaki. Berikut ukuran peti kemas standar:

\begin{tabular}{|c|c|c|c|c|c|c|c|}
\hline & & \multicolumn{2}{|c|}{ Peti kemas 20 kaki } & \multicolumn{2}{|c|}{ Peti kemas 40 kaki } & \multicolumn{2}{|c|}{ Peti kemas 45 kaki } \\
\hline & & inch & metrik & Inch & metrik & inch & metrik \\
\hline \multirow{3}{*}{$\begin{array}{l}\text { dimensi } \\
\text { luar }\end{array}$} & panjang & $20^{\prime} 0^{\prime \prime}$ & $6,058 \mathrm{~m}$ & $40^{\prime} 0^{\prime \prime}$ & $12,192 \mathrm{~m}$ & $45^{\prime} 0^{\prime \prime}$ & $13,716 \mathrm{~m}$ \\
\hline & lebar & $8^{\prime} 0^{\prime \prime}$ & $2,438 \mathrm{~m}$ & $8^{\prime} 0^{\prime \prime}$ & $2,438 \mathrm{~m}$ & $8^{\prime} 0^{\prime \prime}$ & $2,438 \mathrm{~m}$ \\
\hline & tinggi & $8^{\prime} 6^{\prime \prime}$ & $2,591 \mathrm{~m}$ & $8^{\prime} 6^{\prime \prime}$ & $2,591 \mathrm{~m}$ & $9^{\prime} 6^{\prime \prime}$ & $2,896 \mathrm{~m}$ \\
\hline \multirow{3}{*}{$\begin{array}{l}\text { dimensi } \\
\text { dalam }\end{array}$} & panjang & $18^{\prime} 10_{5 / 16}^{\prime \prime}$ & $5,758 \mathrm{~m}$ & $39^{\prime} 5$ 45/64" & $12,032 \mathrm{~m}$ & $44^{\prime} 4^{\prime \prime}$ & $13,556 \mathrm{~m}$ \\
\hline & lebar & $77^{\prime} 8$ 19/32" & $2,352 \mathrm{~m}$ & $7^{\prime} 8$ 19/32" & $2,352 \mathrm{~m}$ & $7^{\prime} 8$ 19/32" & $2,352 \mathrm{~m}$ \\
\hline & tinggi & $7^{\prime} 9_{57 / 64^{\prime \prime}}$ & $2,385 \mathrm{~m}$ & $7^{\prime} 9_{57 / 64^{\prime \prime}}$ & $2,385 \mathrm{~m}$ & $8^{\prime} 9_{15 / 16^{\prime \prime}}$ & $2,698 \mathrm{~m}$ \\
\hline \multirow{2}{*}{$\begin{array}{l}\text { bukaan } \\
\text { pintu }\end{array}$} & lebar & $77^{\prime} 81 / s^{\prime \prime}$ & $2,343 \mathrm{~m}$ & $77^{\prime} 81 / s^{\prime \prime}$ & $2,343 \mathrm{~m}$ & $7^{\prime} 81 / 8^{\prime \prime}$ & $2,343 \mathrm{~m}$ \\
\hline & tinggi & $7^{\prime} 53 / 4^{\prime \prime}$ & $2.2 .80 \mathrm{~m}$ & $7^{\prime} 5 \frac{3}{2 \prime \prime}$ & $2.2 .80 \mathrm{~m}$ & $8^{\prime} 549 / 64^{\prime \prime}$ & $2.585 \mathrm{~m}$ \\
\hline \multicolumn{2}{|l|}{ volume } & $1,169 \mathrm{ft}^{3}$ & $33,1 \mathrm{~m}^{3}$ & $2,385 \mathrm{ft}^{3}$ & $67,5 \mathrm{~m}^{3}$ & $3,040 \mathrm{ft}^{3}$ & $86,1 \mathrm{~m}^{3}$ \\
\hline \multicolumn{2}{|c|}{ berat kotor } & 52.910 pon & $24.000 \mathrm{~kg}$ & 67.200 pon & $30.480 \mathrm{~kg}$ & 67.200 pon & $30.480 \mathrm{~kg}$ \\
\hline \multicolumn{2}{|c|}{ berat kosong } & 4.850 pon & $2.200 \mathrm{~kg}$ & 8.380 pon & $3.800 \mathrm{~kg}$ & 10.580 pon & $4.800 \mathrm{~kg}$ \\
\hline \multicolumn{2}{|c|}{ muatan bersih } & 48.060 pon & $21.800 \mathrm{~kg}$ & 58.820 pon & $26.680 \mathrm{~kg}$ & 56.620 pon & $25.680 \mathrm{~kg}$ \\
\hline
\end{tabular}

\section{6) Stowage Plan}

Merupakan sebuah gambaran informasi mengenai rencana pengaturan muatan diatas kapal yang mana gambar tersebut menunjukkan pandangan samping (denah) serta pandangan atas (profil) dari letak-letak muatan, jumlah muatan, dan berat muatan yang berada dalam palka sesuai tanda pengiriman (onsignment mark) bagi masing-masing pelabuhan tujuannya. Kegunaan dan fungsi dari stowage plan adalah :

- Dapat mengetahui letak tiap muatan serta jumlah dan beratnya.

- Dapat merencanakan kegiatan pembongkaran yang akan dilakukan.

- Dapat memperhitungkan jumlah buruh yang diperlukan.

- Dapat memperhitungkan lamanya waktu pembongkaran berlangsung.

- Sebagai dokumen pertanggung jawaban atas pengaturan muatan.

Terdapat beberapa hal yang perlu dipertimbangkan dalam pembuatan stowage plan, yaitu :

- Agar bisa menghitung stabilitas kapal.

- Dapat menempatkan kondisi dan letak peralatan bongkar muat.

- Menghitung kekuatan geladak.

- Volume ruang muat dan daya angkut kapal.

Jumlah, berat, jenis dan sifat muatan pada tiap-tiap palka.[4] 


\section{Metodologi Penelitian}

Metodologi penelitian yang digunakan meliputi metode pengumpulan data dan metode perangkat lunak. Berikut penjelasannya :

\section{A. Metode Pengumpulan Data}

Metode pengumpulan data yang digunakan dalam penelitian ini adalah sebagai berikut :

a. Studi Literatur

Studi Literatur merupakan teknik pengumpulan data dengan mengumpulkan literature baik berupa jurnal, paper dan bacaanbacaan lainnya yang berkaitan dengan judul penelitian.

b. Observasi

Observasi merupakan teknik pengumpulan data dengan melakukan peninjauan langsung terhadap studi kasus yang diambil dalam hal ini observasi dilakukan pada perusahaan ekspedisi laut.

c. Interview

Teknik pengumpulan data dengan mengadakan tanya jawab secara langsung yang ada kaitannya dengan topik yang diambil.

\section{1) Metode Pembangunan Perangkat Lunak}

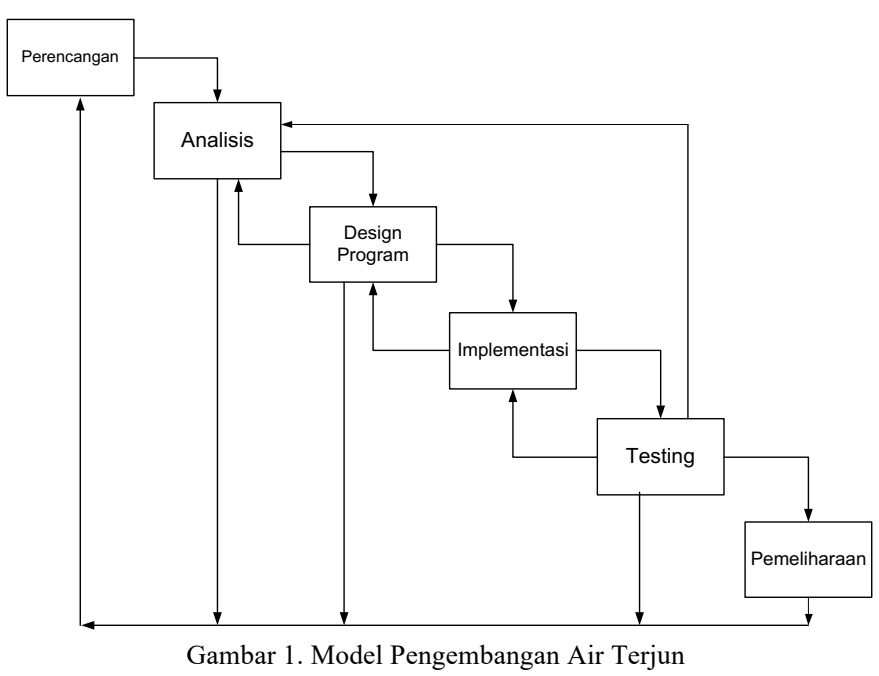

Teknik analisis data dalam pembangunan perangkat lunak menggunakan model waterfall menurut Adi Nugroho, yang meliputi beberapa proses diantaranya yaitu :

a. Perancangan dan analisis

Mengumpulkan kebutuhan secara lengkap kemudian dianalisis dan didefinisikan kebutuhan yang harus dipenuhi oleh program yang akan dibangun. Fase ini harus dikerjakan secara lengkap untuk bisa menghasilkan desain yang lengkap.

b. Design Sistem dan Program

Desain dikerjakan setelah kebutuhan selesai dikumpulkan secara lengkap.

c. Implementasi

Desain program diterjemahkan ke dalam kode-kode dengan menggunakan bahasa pemrograman yang sudah ditentukan. Program yang dibangun langsung diuji baik secara unit. d. Integrasi dan testing.

Penyatuan unit-unit program kemudian diuji secara keseluruhan (sistem testing).

e. Pemeliharaan

Mengoperasikan program di lingkungannya dan melakukan pemeliharaan, seperti penyesuaian atau perubahan karena adaptasi dengan situasi sebenarnya.

\section{HASIL DAN PEMBAHASAN}

A. Aturan dan Jenis Ukuran Barang Beserta Penempatannya Perusahaan jasa pelayaran dengan data barang kiriman sebagai berikut:

TABEL I

TABEL JENIS DAN UKURAN BARANG MUATAN KAPAL NIAGA

\begin{tabular}{llc}
\hline \multicolumn{1}{c}{ Jenis Barang } & Ukuran & Keterangan \\
\hline Beras & $\mathrm{Kg} /$ Ton & Karungan \\
Semen & $\mathrm{Kg} /$ Ton & Karungan \\
Pakan ayam/ternak & $\mathrm{Kg} /$ Ton & Karungan \\
Biji kopi & $\mathrm{Kg} /$ Ton & Karungan \\
Material bangunan & $\mathrm{Kg} /$ Ton & Pallet, Dll \\
Peti kemas kosong & $\mathrm{Kg} /$ Ton & - \\
Cairan Dalam drum & $\mathrm{Kg} /$ Ton & Drum, tangki, \\
& & dll \\
Material $>10$ meter & & \\
\hline
\end{tabular}

TABEL II TABEL POSISI LETAK MUATAN

\begin{tabular}{ll}
\hline \multicolumn{1}{c}{ Jenis barang } & \multicolumn{1}{c}{ Posisi } \\
\hline Barang mengandung cairan & Belakang (dalam palka) \\
Semen & Bawah / dasar palka \\
Material $>10$ meter & Atas tutup palka \\
Mudah terbakar & Bawah (dasar palka) \\
Karungan(Beras,Pupuk,Gula Pasir, & Tengah (dalam palka) \\
Biji Kopi,dll) & \\
Kontainer & Belakang dalam palka \\
Lain-lain depan & (dalam palka / luar \\
& palka) \\
\hline
\end{tabular}

B. Studi Kasus Perhitungan Tonase Barang Material $>10$ Meter Suatu perusahan ekspedisi ingin mengirimkan barang material dengan muatan panjang $11 \mathrm{~m}$, lebar $2 \mathrm{~m}$, dan tinggi 1 meter. Menggunakan rumus menghitung volume barang kiriman via laut yang telah diakui oleh ASPERINDO(Asosiasi Perusahaan Jasa Pengiriman Ekspres, Pos dan Logistik Indonesia) apabila suatu barang dengan ukuran panjang, lebar dan tinggi sebagai berikut:

Panjang $=11$ meter $(1100$ dalam $\mathrm{cm})$

lebar $=2$ meter $(200$ dalam $\mathrm{cm})$

Tinggi $=1$ meter $(100$ dalam $\mathrm{cm})$

Maka gunakan rumus :

$$
\text { Hasil= }=\frac{\text { Panjang } \mathrm{x} \text { lebar } \mathrm{x} \text { Tinggi }}{1000000}
$$

Menghasilkan sebagai berikut :

Hasil=Panjang $\mathrm{x}$ Lebar $\mathrm{x}$ Tinggi

$$
=\frac{1000000}{1000000}
$$




\section{$=22$ kubik}

Maka volume yang didapatkan dari barang muatan dengan panjang 11 meter, lebar 2meter dan tinggi 1 meter adalah 22 Ton C. Halaman Interface

Adapun tampilan dari aplikasi tata letak muatan menggunakan perhitungan tonase dapat dilihat sbb :

1) Tampilan Halaman Login

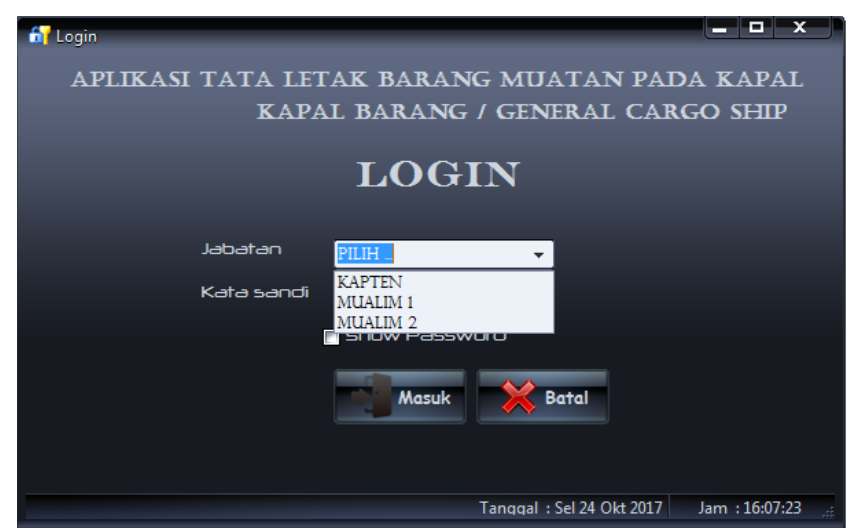

Gambar 2 Tampilan Login

Sebelum login user memilih hak akses dalam aplikasi ini dengan tujuan mencegah adanya perubahan data dari pihak tidak berwenang

2) Login sebagai Mualim I

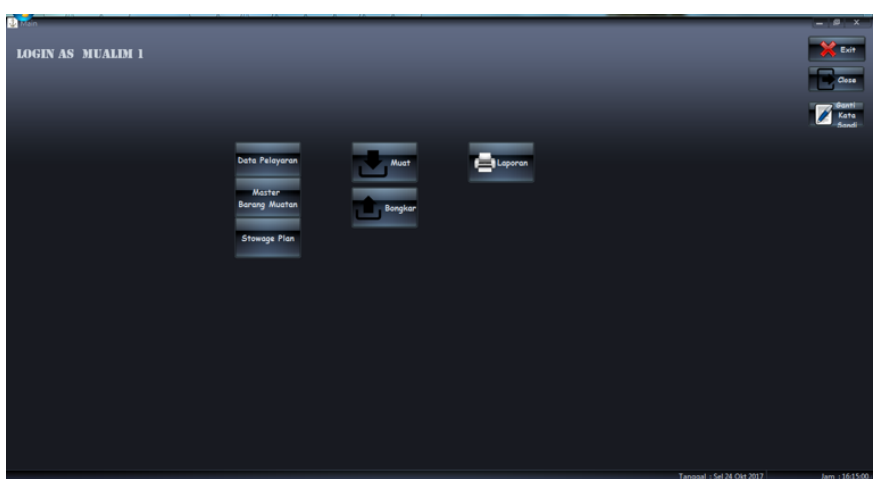

Gambar 3. Tampilan Login sebagai Mualim I

Pada gambar 3 merupakan tampilan menu utama dari akses Mualim I. Mualim I merupakan operator dengan hak akses utama dari aplikasi tata letak barang muatan pada kapal barang

\section{3) Login sebagai Kapten}

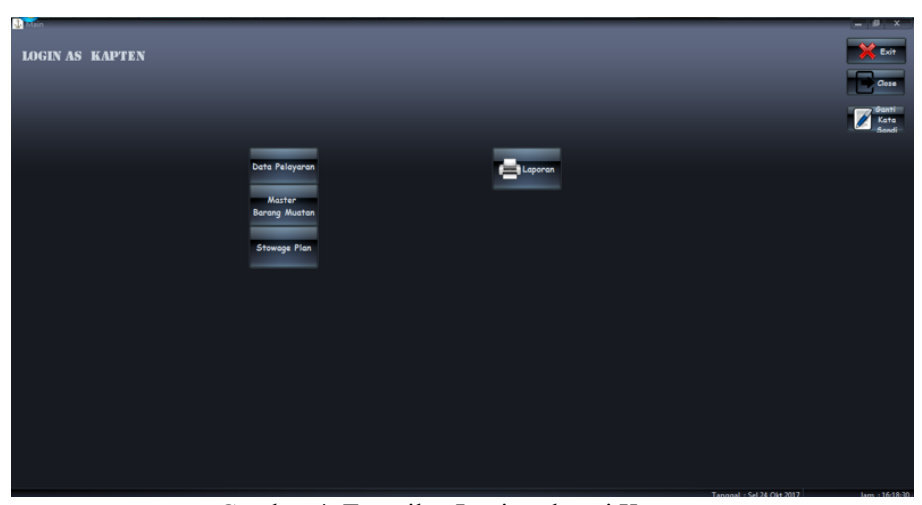

Gambar 4. Tampilan Login sebagai Kapten
Pada gambar 4 merupakan tampilan menu utama dari akses Kapten. Kapten memiliki wewenang dalam menentukan tujuan pelayaran serta melihat data barang yang ada diatas kapal

4) Login sebagai Mualim II

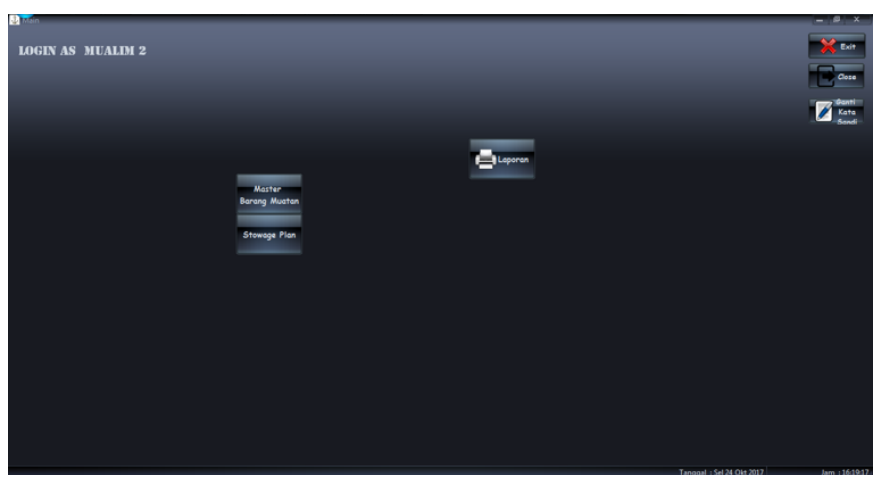

Gambar 5. Tampilan Login sebagai Mualim II

Pada gambar 5 merupakan tampilan menu utama dari akses Mualim II.Mualim II hanya memiliki hak akses dalam melihat data barang yang ada diatas kapal.

5) Proses Muat

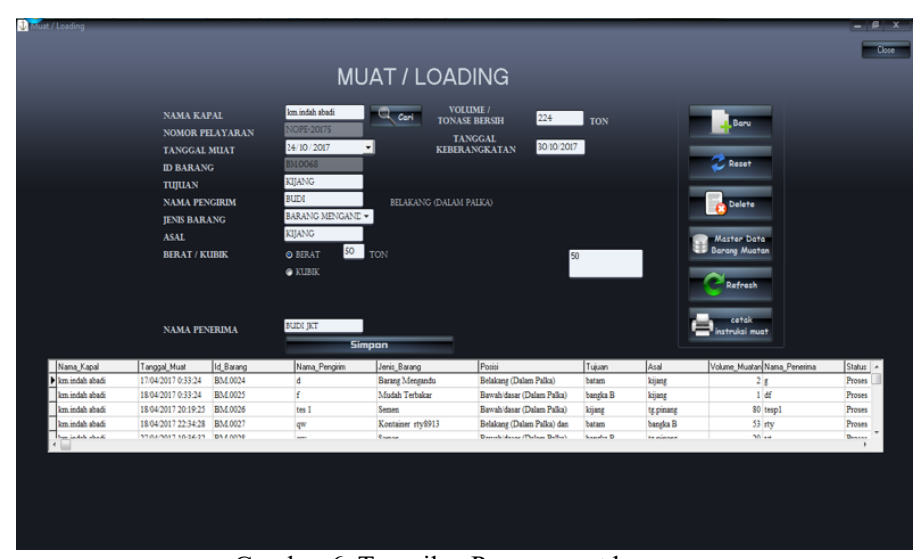

Gambar 6. Tampilan Proses muat barang

Pada proses ini data barang yang akan dimuat ke kapal di masukkan ke aplikasi berupa asal, tujuan, nama pengirim, nama penerima, jenis barang, jumlah dan sistem akan menampilkan tonase bersih atau jumlah tonase yang masih dapat menampung barang dikapal tersebut. ketika proses selesai maka sistem akan memotong atau mengurangi jumlah tonase bersih kapal tersebut dan apabila barang yang akan dimuat kekapal melebihi tonase bersih maka sistem akan menolak (Gambar 6).

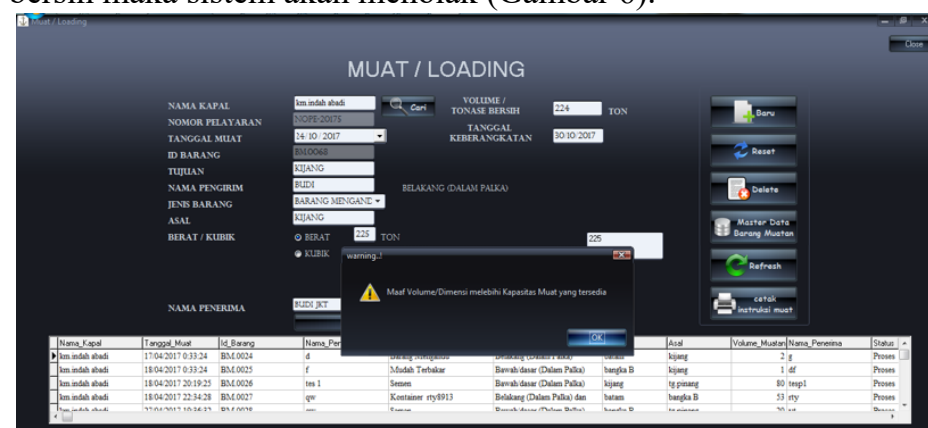

Gambar 7. Tampilan Sistem Menolak Data Barang yang Dimasukkan Melebih Tonase Bersih 
Apabila semua data yang dimasukkan sesuai maka sistem akan menampilkan kotak dialog yang berisikan opsi / pilihan akan mencetak laporan instruksi atau tidak (gambar 7). apabila ingin mencetak laporan instruksi muat maka sistem akan menampilkan preview data barang yang akan dimuat yang nanti setelah dicetak laporan instruksi muat (gambar 8) akan diberikan kepada buruh bongkar muat

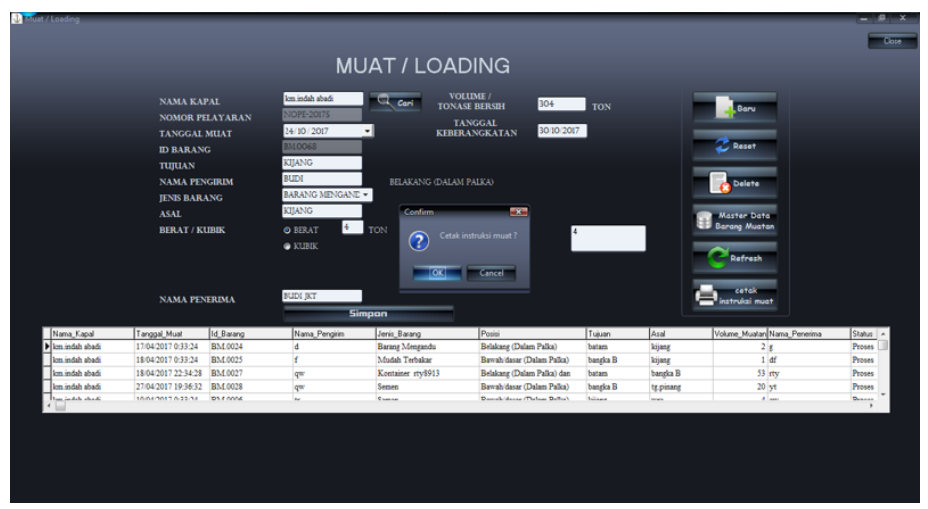

Gambar 7. konfirmasi cetak laporan instruksi muat

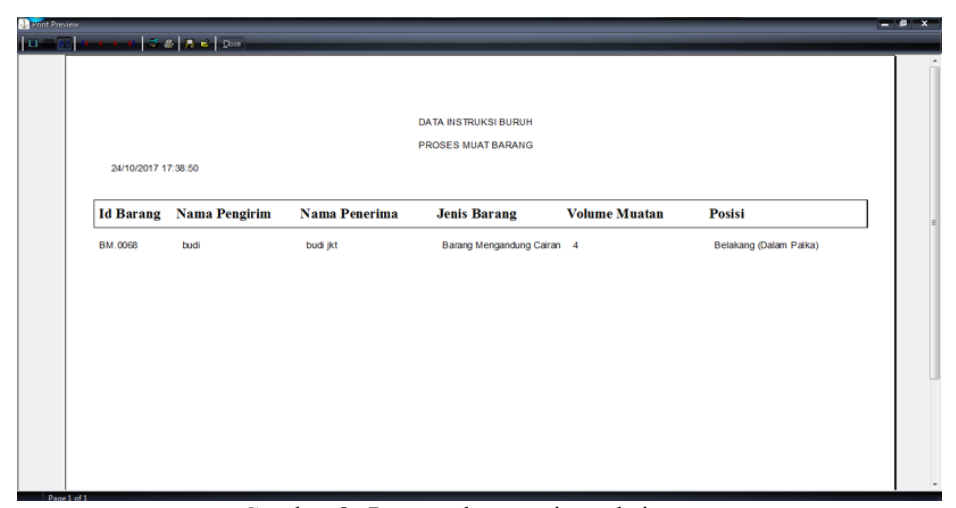

Gambar 8. Preview laporan instruksi muat

\section{6) Proses Bongkar}

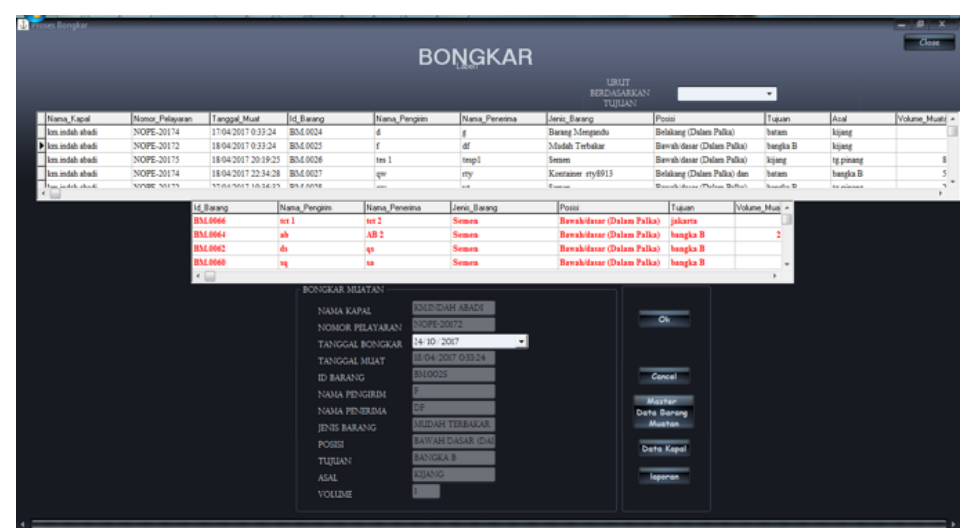

Gambar 9 Tampilan Proses Bongkar Barang Muatan

Gambar 9 tabel 1 berisikan data barang muatan yang ada diatas kapal. ketika memilih salah satu data barang muatan yang akan di proses bongkar maka tabel 2 (warna font merah) akan menampilkan data barang dengan posisi yang sama. setelah barang dilakukan proses bongkar maka tonase bersih kapal akan bertambah. sistem akan merubah Status dari data barang yang dipilih oleh operator (Mualim I) menjadi status "Selesai" dan sistem akan menampilkan kotak dialog yang berisikan opsi / pilihan akan mencetak laporan instruksi atau tidak (Gambar 10). apabila ingin mencetak laporan instruksi bongkar maka sistem akan menampilkan preview (Gambar 11) data barang yang akan dibongkar yang nanti setelah dicetak laporan instruksi muat akan diberikan kepada buruh bongkar muat

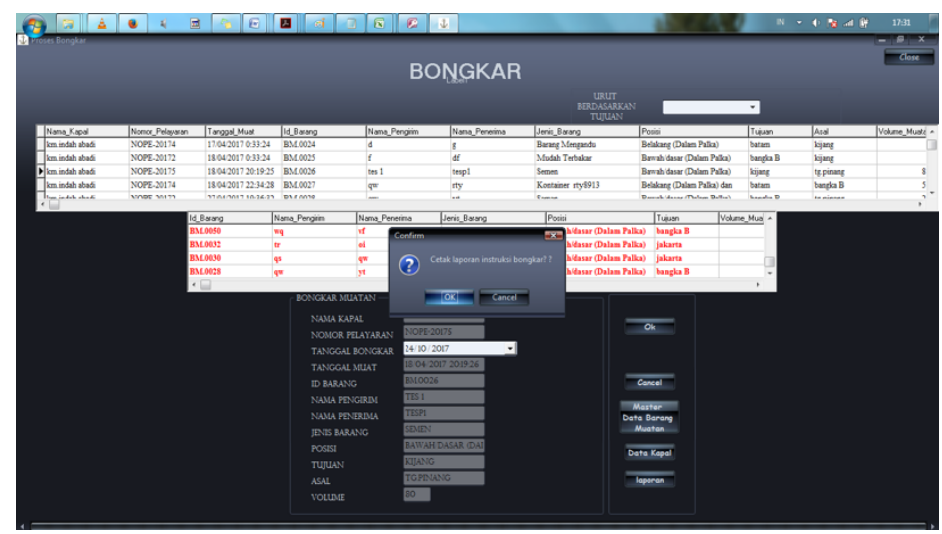

Gambar 10. Tampilan konfirmasi cetak laporan instruksi bongkar

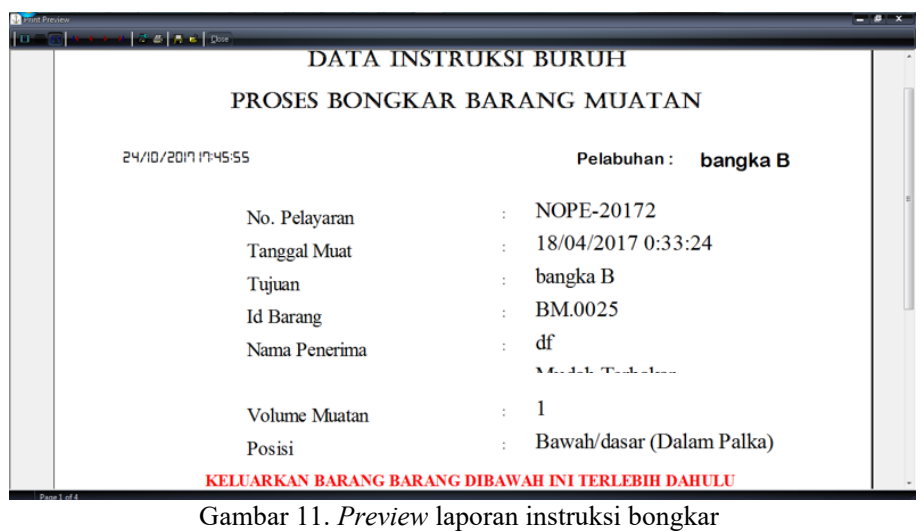

\section{7) Stowage plan}

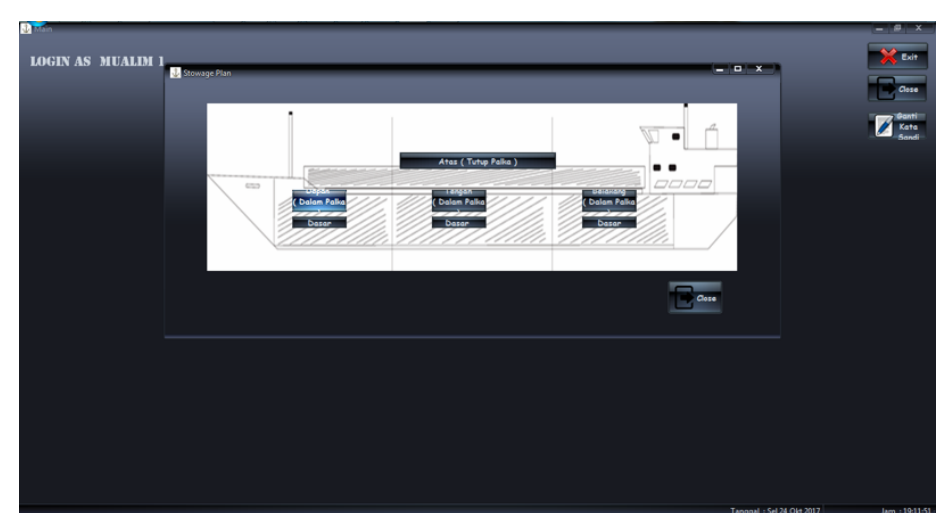

Gambar 12.Tampilan halaman Stowage plan

Stowage Plan merupakan gambaran letak muatan / perencanaan letak barang muatan pada suatu kapal. stowage plan pada aplikasi tata letak muatan pada kapal barang ini menggunakan sistem menampilkan data barang sesuai tombol yang ada pada pola kapal.sistem akan men ampilkan data barang muatan sesuai tombol yang dipilih (gambar 12). 


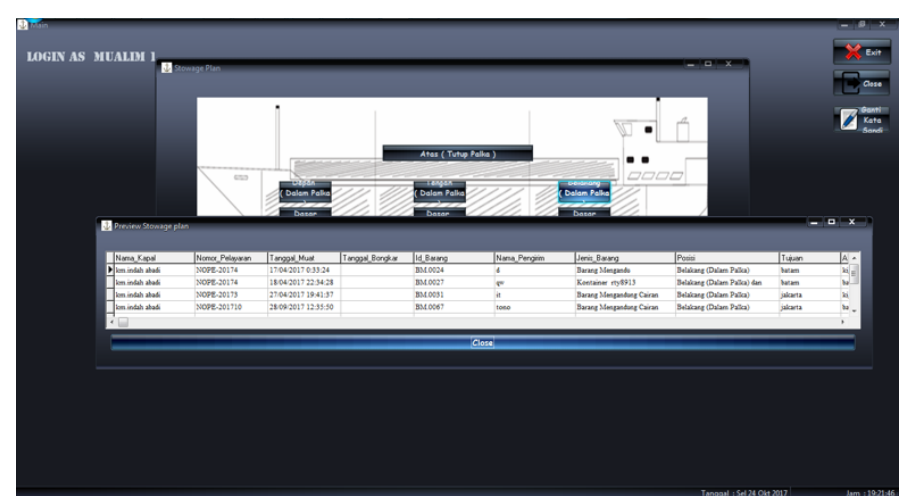

Gambar 13. Data stowage plan

\section{8) Data Pelayaran}

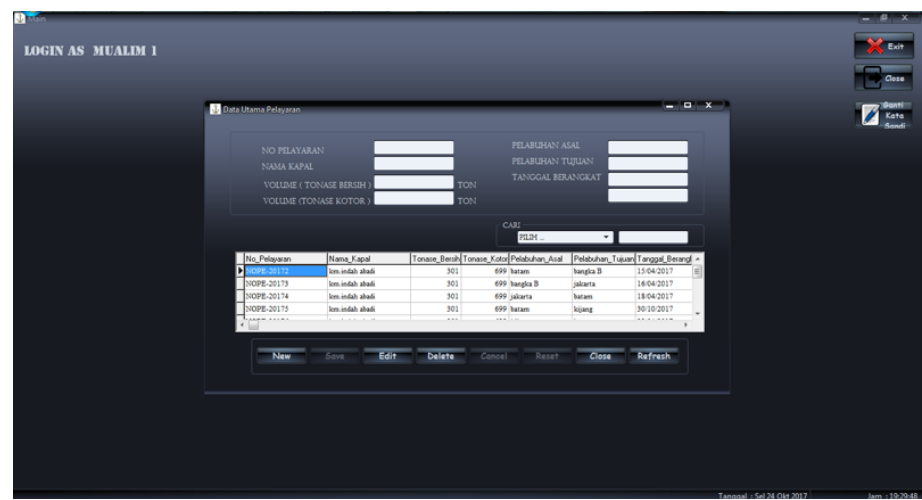

Gambar 14.Tampilan halaman Data pelayaran

Pada halaman data pelayaran berisikan data kapal seperti nomor pelayaran, nama kapal, tonase bersih, tonase kotor, pelabuhan asal, pelabuhan tujuan dan tanggal berangkat. setiap operator melakukan prose Muat dan proses Bongkar maka tonase bersih dan tonase kotor yang ada dihalaman data pelayaran ini akan berubah sesuai tonase/volume yang diinputkan saat porses muat maupun proses bongkar.

\section{9) Master Data Barang Muatan}

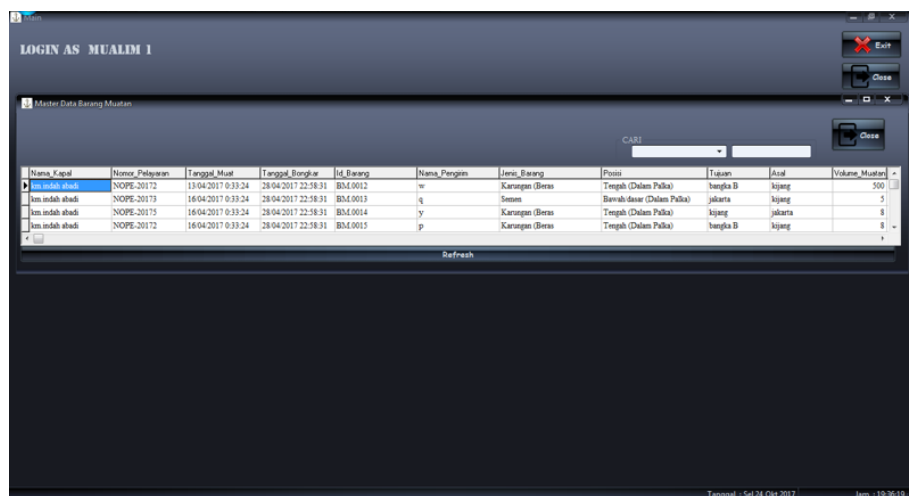

Gambar 15.Tampilan Halaman Master Data Barang Muatan

Master data barang muatan berisikan keseluruhan data barang muatan termasuk yang berstatus Selesai atau telah dilakukan proses bongkar.pada halaman ini operator dapat melakukan pencarian data berdasarkan nomor pelayaran, tanggal muat,tanggal bongkar, id barang, nama pengirim, jenis, posisi, tujuan, asal, volume muatan, nama penerima barang dan status. apabila operator melakukan pencarian suatu barang berdasarkan nama pengirim maka sistem akan menampilkan data yang diinginkan operator(gambar 16).

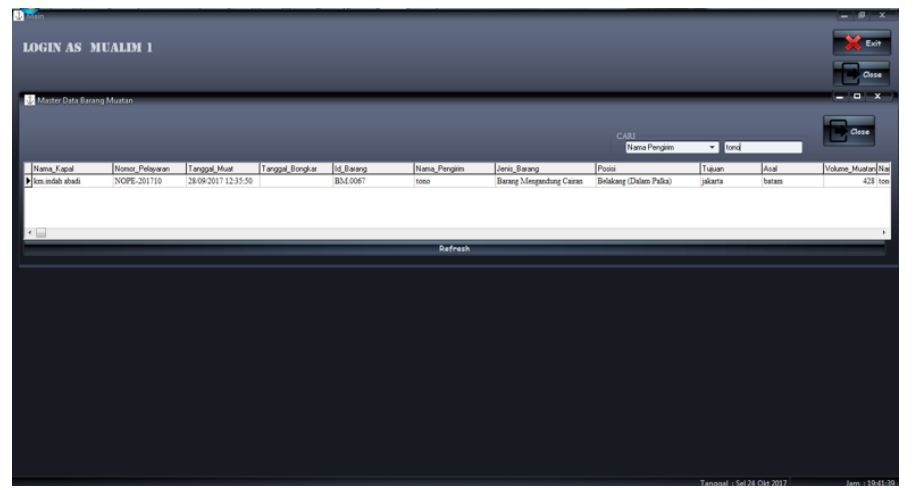

Gambar 16. Tampilan Hasil pencarian berdasarkan nama pengirim

\section{0) Tampilan Menu Laporan}

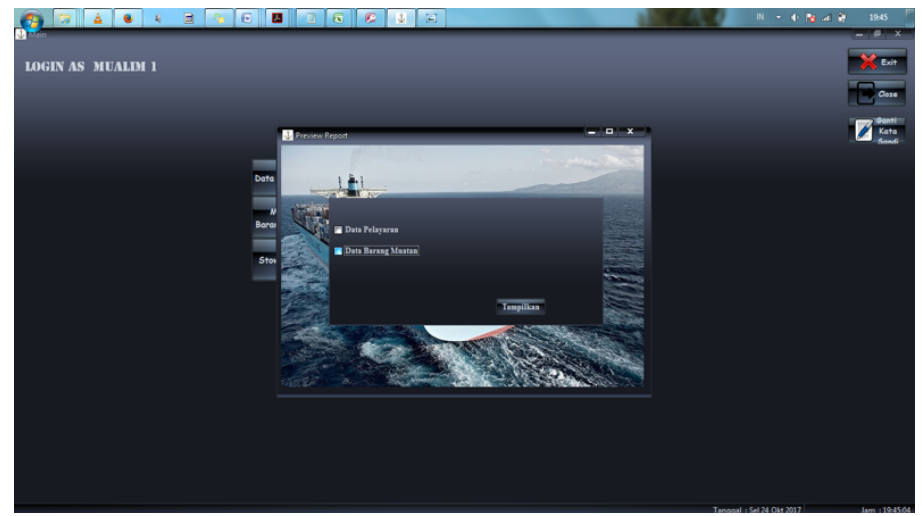

Gambar 17.Tampilan Opsi Preview Laporan Data

Pada halaman ini operator dapat melakukan preview dan cetak laporan data pelayaran dan data barang muatan berdasarkan opsi masing-masing. Apabila operator memilih preview data pelayaran maka sistem akan menampilkan beberapa pilihan sesuai kebutuhan operator(gambar 3.18)

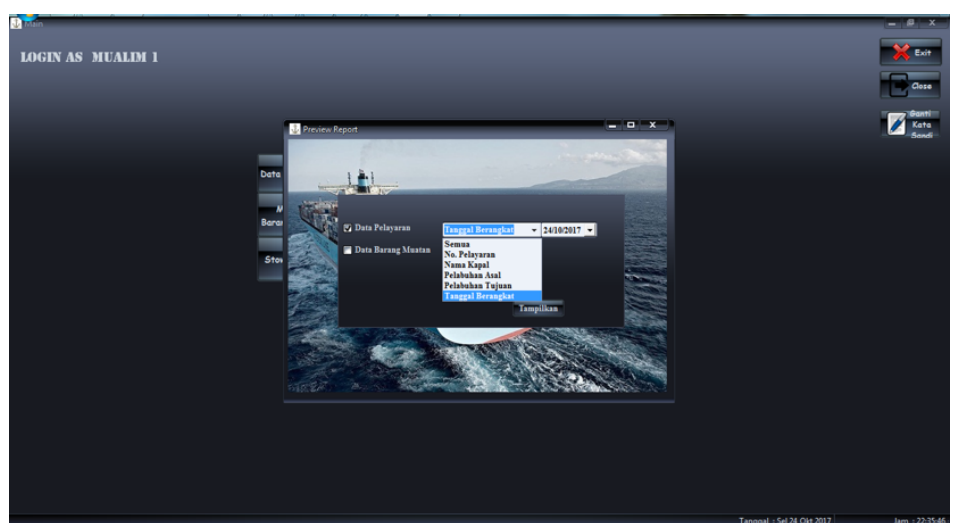

Gambar 18. Opsi laporan data pelayaran

\section{KESIMPULAN}

Berdasarkan hasil analisis hasil dari Aplikasi Tata Letak Muatan Pada Kapal Barang, maka dapat diambil kesimpulan sebagai berikut :

1. Penggunaan aplikasi Aplikasi tata letak muatan barang pada kapal barang dapat membantu pihak perusahaan 
pelayaran dalam mendapatkan data khususnya kapasitas ruang muat yang dapat diisi secara maksimal.

2. Sangat membantu perwira kapal dalam mendapatkan data berat barang yang ada diatas kapal sehingga proses pengambilan keputusan dalam memilih alur laut dapat dilakukan secara efektif.

3. Dengan tertata nya letak muatan sesuai jenis sangat membantu dalam mencegah kerusakan barang muatan dan dapat meminimalisir kerugian terhadap perusahaan

4. Dengan adanya aplikasi ini dapat mengurangi kesalahan yang ditimbulkan oleh faktor kelalaian manusia yang diakibatkan dari banyaknya data yang dihitung secara manual dan proses pencarian data menjadi lebih efektif.

\section{REFERENSI}

[1] Winarno, Edy, Pembangunan aplikasi child tracker berbasis assisted - global positioning system (a-gps) dengan platform android.2013

[2] Sukarto Haryono. 2006. Transportasi Perkotaan dan lingkungan,Tangerang:.Jurnal Teknik Sipil. Vol.3,No.2:93.

[3] Muryaningsing, Ika, Pelaksanaan Bongkar Muat Barang Oleh PT. Dharma Lautan Nusantara di Pelabuhan Tanjung Emas Semarang, 2006

[4] Yudha, Maulana Perdana, Upaya Penanganan Hambatan Bongkar Muat lpg Type-C Di Kapal Mt. Gas Indonesia, DIV Nautika Semarang, Skripsi, Politeknik Ilmu Pelayaran semarang, 